Seismic monitoring

\section{Station goes with a bang}

THE Soviet-US seismic monitoring expedition to Karkaralinsk in Kazakhstan is essentially a confidence-building exercise aimed at showing it is possible to detect infringements of any future nuclear testban treaty, according to Oleg Stolyarov, a laboratory head from the Schmidt Institute of Earth Physics of the Soviet Academy of Sciences.

The expedition has been a unique cooperative venture that has allowed a team of US scientists to set up a seismic monitoring station in the Soviet Union. The Soviet side will reciprocate later and help to set up a station in Nevada. But the US government has not been involved: the

\section{IMAGE \\ UNAVAILABLE FOR COPYRIGHT REASONS}

agreement is between the National $\mathrm{Re}$ sources Defense Council, a private environmental group, and the Soviet Academy of Sciences (see Nature 321, $638 ; 1986)$.

Stolyarov, who has been acting as spokesman for the Soviet side, maintains that all the scientists on the expedition agree that seismic tremors can be monitored with sufficient accuracy to detect nuclear tests. The real purpose of the exercise, he maintains, is to convince the US authorities, who would prefer not to believe it.

Since the US participants do not have government backing, Stolyarov may have assumed that the government was hostile to the project. Other difficulties may have helped confirm this impression. As CoCom regulations forbid the export of Western state-of-the-art technology to the Soviet bloc, the US equipment taken to Karkaralinsk was somewhat outmoded

In the event, the Americans working at Karkaralinsk, a geological freak area where outcrops of bedrocks that are highly conductive to vibrations make it a natural seismic observation site, obtained excellent signals from nuclear blasts in Nevada.

Despite the political tensions generated by US reluctance to follow the Soviet example of declaring a nuclear moratorium, the two teams are said by Stolyarov to have "worked hard in a friendly way. . brought together by a noble purpose".

\title{
Ariane ride for Indian satellite
}

\section{Bangalore}

THE Ariane launch vehicle of the European Space Agency (ESA) will launch India's multi-purpose domestic satellite INSAT$1 \mathrm{C}$ in early 1988 according to an agreement signed between the Indian Space Department and Paris-based Arianespace. This agreement brings to an end uncertainty over the launching of INSAT-1C, originally planned for the space shuttle (see Nature 322,$198 ; 1986$ ).

The INSAT spacecraft, described as the first civilian geostationary satellite to combine telecommunications, direct television broadcasting and meteorological observation tasks, are being built by the Ford Aerospace Communications Corporation (FACC) of Palo Alto, California, under a contract from the Indian Space Department.

With a launch weight of $1,180 \mathrm{~kg}$, INSAT-1C is similar in configuration and performance to INSAT-1B, now in orbit. INSAT-1A, the first in the series, was launched in April 1982 but was switched off six months after its launch following a series of malfunctions. INSAT-1B went up in August 1983 and is running smoothly. All the spacecraft are designed for seven years active life in orbit. Successful launch of INSAT-1C will complete plans to have one operational satellite and one spare in orbit. INSAT-1D is expected to be launched in late 1988 or early 1989.

According to Professor U. R. Rao, secretary of the Indian Space Department, Arianespace offered the only competitive option after the shuttle failure had been followed by problems with the US conventional launcher, the Delta rocket. He said that the European launching system is as good as the US system although it is a little costlier at US \$33 million. "But the French have gone out of their way to accommodate us", he said.

Frederic d'Allest, chairman of Arianespace, and Rao hailed the agreement as a

milestone in the long-standing and steadily growing cooperation in the field of space between India and Europe in general and France in particular. They are confident of further expansion of Indo-French cooperation in other areas such as remote sensing, satellite-aided search and rescue for the benefit of both countries.

Meanwhile, India is busy designing the second-generation INSAT spacecraft which will be built and launched in India. A liquid oxygen/liquid hydrogen launcher is being developed. Radhakrishna Rao

\section{Doing things the all-American way}

\section{Washington}

A BILL that would limit European and Japanese participation in the US Strategic Defense Initiative (SDI) has passed the Senate, and will be acted on by the House of Representatives this week. In a rare Saturday session, the Senate adopted an amendment, sponsored by Senator John Glenn (Democrat, Ohio), to the defence authorization bill that would prohibit the SDI office from signing contracts with foreign companies unless the Secretary of Defense certified that the work could not be performed in the United States. The amendment does not cover work subcontracted to companies outside the United States.

In the House of Representatives, a similar amendment, sponsored by Representative Les AuCoin (Democrat, Oregon), would place a size limit of $\$ 100,000$ on SDI contracts with non-US companies. AuCoin's amendment does not permit ex- ceptions. The House amendment is intended both to provide additional jobs for US workers and to prevent the Reagan administration from buying support for SDI from US allies with fat research contracts. It was impossible earlier this week to estimate the amendment's chances of success.

The Federation of American Scientists estimates that foreign SDI contracts at present amount to $\$ 75$ million. Although this represents only a small fraction of SDI's 1986 budget of $\$ 3,050$ million, some countries clearly hope for a much larger role in the project (see Nature, 322, 300; 1986).

The version of the defence authorisation bill passed by the Senate would limit spending on SDI to $\$ 3,950$ million, well below the administration's $\$ 5,400$ million budget request. That figure is likely to be trimmed even further in the House of Representatives' version. Joseph Palca 